Anais da Academia Brasileira de Ciências (2006) 78(3): 591-605

(Annals of the Brazilian Academy of Sciences)

ISSN 0001-3765

www.scielo.br/aabc

\title{
Paleomagnetic constraints on the age of the Botucatu Formation in Rio Grande do Sul, Southern Brazil
}

\author{
ENDALE TAMRAT and MARCIA ERNESTO \\ Instituto de Astronomia, Geofísica e Ciências Atmosféricas, Departamento de Geofísica, \\ Universidade de São Paulo, Rua do Matão 1226, 05508-090 São Paulo, SP, Brasil \\ Manuscript received on November 12, 2005; accepted for publication on February 5, 2006; \\ presented by MARTA S.M. MANTOVANI
}

\begin{abstract}
Paleomagnetic and rockmagnetic data are reported for the aeolian Botucatu Formation, in the southern Brazilian State of Rio Grande do Sul. Oriented samples were taken from a section located between the cities of Jaguari and Santiago. After thermal and alternating field demagnetization, both normal and reversed characteristic remanent magnetizations were found. These results yielded 13 reversed and 5 normal polarity sites, composing a magnetostratigraphic column displaying a sequence of reversed-normal-reversed polarity events. The paleomagnetic pole calculated for 18 sites is located at $114.7^{\circ} \mathrm{E}, 78.5^{\circ} \mathrm{S}\left(\mathrm{dp}=8.1^{\circ} ; \mathrm{dm}=1.2^{\circ}\right)$, after restoring the strata to the paleohorizontal. This paleomagnetic pole indicates a Late Jurassic-Early Cretaceous age to the Botucatu Formation in the investigated area, and places the sampling sites at paleolatitudes as low as $21^{\circ} \mathrm{S}$.
\end{abstract}

Key words: paleomagnetism, Botucatu Formation, magnetostratigraphy, magnetic anisotropy, Late Jurassic.

\section{INTRODUCTION}

The Mesozoic history of the Paraná Basin is marked by large-scale desert conditions, evidenced by the accumulation of aeolian dunes throughout the basin beginning in the Triassic. Assine et al. (2004) refer to the dry Botucatu paleodesert that followed the more humid conditions of the Pirambóia paleodesert. Desert conditions prevailed during the magmatic activity that gave rise to the Early Cretaceous Serra Geral Formation prior to the separation of the South American and African plate. Arid to semiarid climatic conditions mark the deposition of the post-volcanic Bauru Group (Dias-Brito et al. 2001) of Late Cretaceous age. This scenario delineates an interval of dry climatic conditions that

Correspondence to: Marcia Ernesto

E-mail: marcia@iag.usp.br persisted for at least 120 million years. Within this period the South American plate was involved in two continental breakup events that caused the disruption of Pangea and Gondwana, with the consequent opening of the Central and South Atlantic Oceans, respectively.

Tectonic controls on the oceanographic and climatic conditions have played an important role on the deposition of the aeolian sediments of the Botucatu Formation, and elsewhere in other Brazilian sedimentary basins as mentioned by Assine et al. (2004). Therefore valuable information about the regional environment are tied to global change of the oceanic-atmospheric system. In order to better understand this link, we seek to establish the conditions attending the deposition of the Botucatu Formation including the establishment of better age 
control on the onset of the deposition system.

Aeolian deposits, such as the Botucatu Formation, are generally devoid of the index macroand micro-fossils. Consequently, any attempt to define the chronostratigraphy is highly doubtful. In the present case chronostratigraphic correlation can be retrieved only in relative terms from the overlying volcanic sequence of the Serra Geral Formation. Paleomagnetism appears to be the most promising method to eliminate the age uncertainties through the determination of a paleomagnetic pole and comparison with other available paleopoles for the South America continent. With this purpose we present here results of one section of the Botucatu Formation sampled in the Rio Grande do Sul State.

\section{GEOLOGICAL SETTING}

The Botucatu Formation (BF) is a widespread aeolian sandstone unit characterized by crossbedding. This formation occupies a large area in southern Brazil, Uruguay, Paraguay and Argentina. The existence of similar deposits in Africa point to a total extent of this former desert of more than 1.5 million $\mathrm{km}^{2}$ (Almeida 1954, Salamuni and Bigarella 1967).

The BF was deposited as an immense sand sea of large aeolian dunes in which wet interdunes were absent (Scherer 2000). At its base, the BF locally includes coarse-grained strata composed of conglomerates and gravelly sandstones deposited by ephemeral streams, and coarse-grained sandstones interpreted as sand sheets (Soares 1975, Almeida and Melo 1981). The base rests unconformably over the sediments of the Pirambóia Formation which are also predominantly aeolian in nature, although Assine et al. (2004) proposed that the Botucatu and Pirambóia sediments represent two distinct desert systems.

The BF is overlain by the lava flows of the Serra Geral Formation, which however, did not destroy the morphology of the dunes (Almeida 1954). Thin aeolian deposits ( $\sim 10 \mathrm{~m}$ ) of limited extent occur intercalated with the volcanic rocks, suggesting that the desert conditions persisted throughout the vol- canic episode (Milani et al. 1999). The BF thins southward and is absent in some areas of the central portion of Rio Grande do Sul State where the volcanics directly overlie fluvial and lacustrine Triassic deposits. Thickness of the Botucatu Formation is quite variable, reaching a maximum of $100 \mathrm{~m}$. Facies are composed of fine to coarse grained sandstones displaying crossbedding (Scherer 2000).

The age of BF is highly debatable. In various portions of Rio Grande do Sul State the Botucatu Formation overlies discordantly either the Caturrita Formation or Santa Maria Formation, both of which are of Triassic age, as indicated by the presence of vertebrate fossil assemblages. The BF must be younger than those rocks. A Late Triassic to Early Jurassic was assigned to the BF on the basis of vertebrate footprints (Rhaetian/Hettangian; Bertini 1993), in contrast with the end Early to midJurassic determined from the same evidence by Leonardi and Oliveira (1990). On the other hand, Scherer (2000) considers an Early Cretaceous age to be more reasonable, on the basis of concordant contact with the Serra Geral basalts (Early Cretaceous), and evidences for a short time interval for deposition. However, all ages may be admissible considering that the deposition desert regime sediment was not necessarily contemporaneous all over the basin.

\section{SAMPLING AND LABORATORY TECHNIQUES}

The Botucatu Formation was sampled in roadcuts between the cities of Jaguari and Santiago in the Rio Grande do Sul State (Fig. 1). Sandstones in these sections were reddish to light brown in color, and generally fine to medium grained. Hand-samples oriented by both sun and magnetic compasses were taken from 28 stratigraphic levels, comprising a vertical section of more than $35 \mathrm{~m}$ (Fig. 1), although discontinuous due to vegetation covering. Some sites, mainly from the upper part of the section, showed variable dips up to $33^{\circ}$ to the $\mathrm{SW}$, probably more reflective of geometry of the crossbeds than tectonic tilting. The first Serra Geral basalt flow in the 



Fig. 1 - Simplified geological map showing the Botucatu exposure area in the Rio Grande do Sul State, based on E.L. Lavina (unpublished data). The smaller box shows section from where oriented samples were taken.

area was found about $700 \mathrm{~m}$ northward, about $50 \mathrm{~m}$ above the last sampling point of the northern sector (JS105) of the section and almost at the same level of sampling point JS120 (southern sector).

In the laboratory three to seven standard cylindrical paleomagnetic specimens were drilled from each block yielding a total of 156 specimens. Natural remanent magnetization (NRM) was measured in a $2 \mathrm{G}$-Enterprises cryogenic magnetometer with an automated sample handler and in-line alternating field (AF) unit. The measurement was conducted both at the paleomagnetic laboratory of the Univer- sity of São Paulo (IAG-USP) and in the magnetically shielded room facility of the Berkeley Geochronology Center (Berkeley, California). A Schonstedt-TSD1 shielded furnace has been used for thermal demagnetization. Identification of remanent magnetization components was performed by orthogonal vector diagrams (Zijderveld 1967) and principal component analysis (Kirschvink 1980). Site mean characteristic directions were calculated by giving unit weight to specimens, and uncertainties were evaluated by Fisher's (1953) statistics.

Natural remanent magnetization (NRM) of 

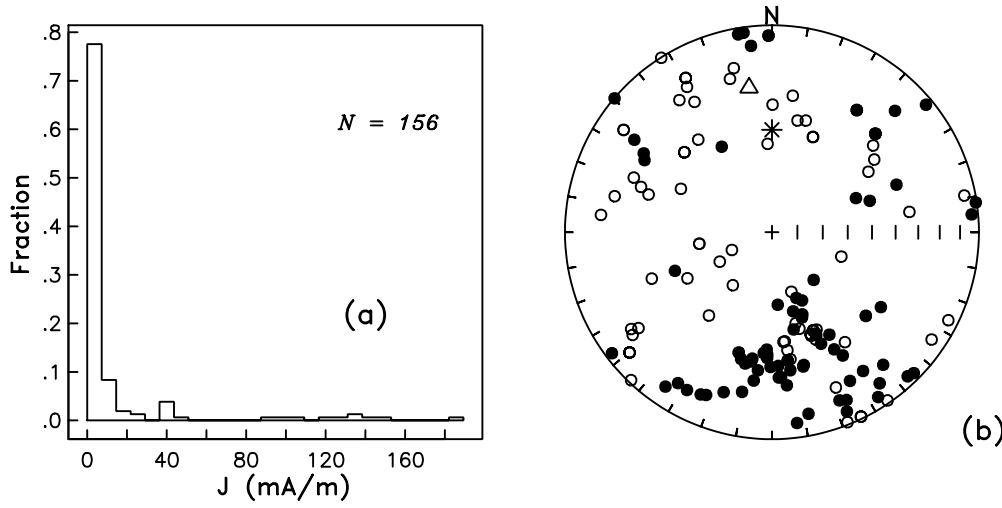

Fig. 2 - (a) Distribution of the NRM, and (b) equal area projection of NRM directions of 156 samples of the Botucatu Formation. Solid (open) circles represent positive (negative) magnetic inclinations, triangle is the present day geomagnetic field direction in the sampling area, and star is the axial dipole direction.

156 cylindrical samples was measured. Initial NRM intensities of $80 \%$ of the samples were less than $0.5 \mathrm{~mA} / \mathrm{m}$ (Fig. 2a) and in situ NRM directions were highly scattered (Fig. 2b) and far from the present local geocentric axial dipole field direction $\left(\mathrm{D} / \mathrm{I}=0^{\circ} /-49^{\circ}\right)$. After alternating field and thermal demagnetizations ranging from 3 to $170 \mathrm{mT}$ and 100 to $680^{\circ} \mathrm{C}$ (Figs. 3 and 4), respectively, two polarity groups were identified. Reversed polarity sites belong almost exclusively to northern sector of the section (basal portion), and display two magnetic components: a low to medium coercivity (up to $20 \mathrm{mT}$ ) and low unblocking temperature $\left(200^{\circ} \mathrm{C}\right)$ component (LT-R), and a high coercivity component $(>20 \mathrm{mT})$ that represents the characteristic remanent magnetization (ChRM) of the reversed polarity group. The mean of 30 LT-R directions (Table I) coincides with the mean magnetization of the Serra Geral lava flows in the study area (JS section; Ernesto et al. 1990). The reversed polarity ChRM commonly unblocked in the temperature range 300 to $600^{\circ} \mathrm{C}$ (Fig. 3), and was easily resolved in Zijderveld diagrams due to a linear decay to the origin, and fit through ten consecutive demagnetization steps, with maximum angular deviation (MAD) less than $7^{\circ}$.

Although the polarity was clearly determined, the ChRM was difficult to isolate in samples from upper part of the section (southern sector). Magnetization of sister specimens showed same trajectories during both thermal and AF demagnetizations, however, AF data is less "noisy" than thermal demagnetization data. Mean magnetization direction computed using only thermal demagnetization data differs by less than $4^{\circ}$ from the mean based only on AF data. Therefore, AF demagnetization was applied to the rest of specimens from each site. Three of the 15 sites (20 specimens) gave no consistent directions of magnetization and were discarded (Table I). For the remaining 12 sites only 5 sites yielded well defined ChRMs all with normal polarity; 7 sites showed large withinsite scatter $\left(\alpha_{95}>\right.$ $10^{\circ}$ ) or anomalous magnetization that were rejected for the paleomagnetic pole calculation.

\section{ROCK MAGNETISM}

Curie temperatures were determined from thermomagnetic curves obtained in KLY-CS3 and MS-2 Bartington apparatus. Magnetic hysteresis parameters were determined in a Vibrating Sample Magnetometer (VSM).

The magnetic susceptibility of small quantities of crushed samples $(\sim 0.6 \mathrm{~g})$ was measured at increasing temperatures, from room temperature up to $700^{\circ} \mathrm{C}$, in a $\mathrm{KLY}-3$ susceptibility bridge with a 
TABLE I

Paleomagnetic data for the Botucatu formation $\left(29.3^{\circ} \mathrm{S} ; 54.5^{\circ} \mathrm{W}\right)$.

\begin{tabular}{|c|c|c|c|c|c|c|c|c|c|c|c|}
\hline \multirow[b]{2}{*}{ Sample } & \multirow[b]{2}{*}{$\begin{array}{l}\text { Relative } \\
\text { position }\end{array}$} & \multirow[b]{2}{*}{$\begin{array}{c}\text { Altitude } \\
\text { (m) }\end{array}$} & \multicolumn{5}{|c|}{ Mean Magnetization Direction } & \multicolumn{4}{|c|}{ Virtual Geomagnetic Pole } \\
\hline & & & $\mathrm{N}$ & $\begin{array}{c}\text { Dec. } \\
\left({ }^{\circ}\right)\end{array}$ & $\begin{array}{c}\text { Inc. } \\
\left({ }^{\circ}\right)\end{array}$ & $\begin{array}{l}\alpha_{95} \\
\left({ }^{\circ}\right)\end{array}$ & $\mathrm{k}$ & $\begin{array}{c}\text { Long. } \\
\left({ }^{\circ}\right)\end{array}$ & $\begin{array}{l}\text { Lat. } \\
\left({ }^{\circ}\right)\end{array}$ & $\begin{array}{l}\mathrm{dp} \\
\left(^{\circ}\right)\end{array}$ & $\begin{array}{l}\mathrm{dm} \\
\left(^{\circ}\right)\end{array}$ \\
\hline $120 *$ & 49 & 330 & 4 & 255.7 & 61.3 & 17.5 & 29 & 250.4 & -29.3 & 15.0 & 31.8 \\
\hline $119 *$ & 47 & & 5 & 155.5 & -48.2 & 8.4 & 84 & 101.5 & -26.9 & 6.8 & 11.2 \\
\hline $118 *$ & 45.5 & & 4 & - & - & - & - & - & - & - & - \\
\hline $117 *$ & 45.5 & & 2 & 349.7 & 5.3 & 19.8 & & 286.6 & 56.6 & 30.6 & 10.9 \\
\hline $116^{*}$ & 45.0 & & 4 & 234.6 & -16.8 & 7.3 & 159 & 188.5 & -25.2 & 5.6 & 6.9 \\
\hline $115^{*}$ & 44.0 & & 2 & 42.2 & -9.4 & 13.3 & & 12.1 & 43.2 & 16.0 & 9.8 \\
\hline $114^{*}$ & 41.0 & 290 & 12 & - & - & - & - & - & - & - & - \\
\hline 113 & 39.0 & & 2 & 356.4 & -42.2 & 12.5 & & 8.2 & 80.1 & 24.4 & 2.9 \\
\hline 112 & 37.5 & & 4 & 356.4 & -44.2 & 8.7 & 113 & 261.2 & 85.4 & 17.3 & 1.0 \\
\hline 111 & 36.0 & & 5 & 354.8 & -33.3 & 7.9 & 100 & 281.2 & 77.9 & 15.3 & 2.0 \\
\hline $110^{*}$ & 34.5 & & 4 & - & - & - & - & - & - & - & - \\
\hline 109 & $?$ & & 3 & 354.9 & -51.9 & 9.8 & 159 & 177.8 & 84.6 & 19.5 & 1.5 \\
\hline 108 & 32.5 & & 3 & 249.4 & -55.3 & 10.2 & 148 & 176.6 & 78.9 & 19.8 & 3.4 \\
\hline $107 *$ & 30 & & 4 & 308.3 & -18.3 & 39.4 & 6 & 227.0 & 37.8 & 41.9 & 32.8 \\
\hline $106^{*}$ & 30 & 270 & 3 & 75.8 & 7.0 & 10.3 & 143 & 25.3 & 10.6 & 5.7 & 10.2 \\
\hline 105 & 15 & 255 & 3 & 174.5 & 45.9 & 4.8 & 657 & 55.5 & -84.8 & 9.5 & 0.6 \\
\hline 104 & 14.5 & & 3 & 175.5 & 44.1 & 4.3 & 825 & 75.3 & -84.7 & 3.4 & 5.4 \\
\hline 103 & 12.5 & & 6 & 162.4 & 28.9 & 5.7 & 139 & 72.2 & -68.7 & 5.9 & 11.3 \\
\hline 102 & 11 & & 8 & 156.9 & 44.8 & 7.6 & 54 & 38.0 & -69.4 & 4.9 & 9.8 \\
\hline 101 & 10.5 & & 5 & 179.0 & 30.7 & 5.6 & 188 & 121.2 & -77.2 & 3.5 & 6.2 \\
\hline 100 & 10 & & 5 & 167.5 & 32.7 & 4.3 & 316 & 77.9 & -73.8 & 2.8 & 4.9 \\
\hline 99 & 8.5 & & 5 & 151.2 & 35.6 & 5.8 & 133 & 49.1 & -62.2 & 3.9 & 6.8 \\
\hline 98 & 7.7 & & 4 & 163.5 & 35.7 & 3.8 & 575 & 64.3 & -72.2 & 2.6 & 4.4 \\
\hline 97 & 7.2 & & 6 & 176.9 & 39.6 & 5.2 & 167 & 102.6 & -82.6 & 3.7 & 6.2 \\
\hline 96 & 8 & & 5 & 166.4 & 36.0 & 10.6 & 53 & 69.5 & -74.5 & 7.2 & 12.3 \\
\hline 95 & 6 & & 6 & 162.9 & 43.8 & 7.3 & 86 & 45.1 & -74.7 & 5.7 & 9.1 \\
\hline 94 & 2 & & 5 & 166.5 & 32.9 & 6.2 & 116 & 75.2 & -73.2 & 3.9 & 7.0 \\
\hline \multirow[t]{6}{*}{93} & 0 & 230 & 4 & 155.1 & 33.3 & 6.7 & 132 & 56.0 & -64.7 & 4.3 & 7.6 \\
\hline & LT-R & & 30 & 175.0 & 33.5 & 9.4 & 9 & 101.7 & -78.2 & 18.2 & 2.3 \\
\hline & Means & R-polarity & 13 & 165.9 & 37.5 & 4.6 & 82 & 65.1 & -74.8 & 8.7 & 1.5 \\
\hline & & N-polarity & 5 & 354.6 & -45.4 & 8.4 & 84 & 240.0 & 84.7 & 16.7 & 1.1 \\
\hline & & Mixed & 18 & 168.1 & 39.8 & 4.2 & 68 & 64.7 & -77.4 & 8.1 & 1.2 \\
\hline & & Corrected & & 177.8 & 32.9 & & & 114.7 & -78.5 & & \\
\hline
\end{tabular}

$\mathrm{N}=$ number of specimens in the means; Dec. and Inc.= Declination and Inclination; $\alpha_{95}$ and k $=$ Fisher's (1953) statistical parameters; Pol. = polarity $(\mathrm{N}=$ normal, $\mathrm{R}=$ reversed $)$; $\mathrm{dp}$ and $\mathrm{dm}=95 \%$ confidence oval. 


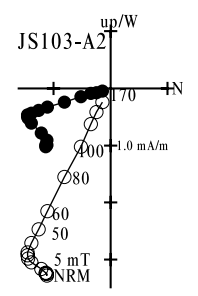

(d)
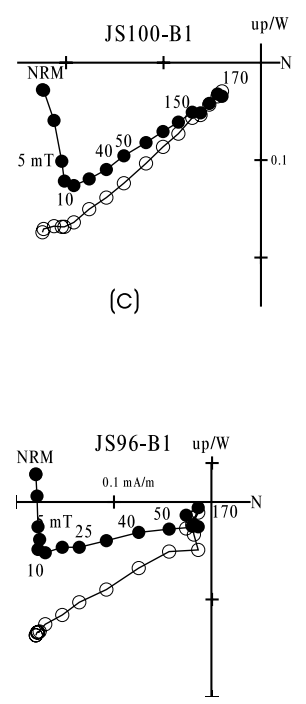

(b)

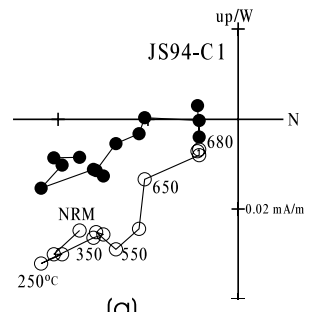

(a)



Fig. 3 -Examples of progressive AF and thermal demagnetization results of samples with reversed magnetic polarity. Right diagrams show the decay of intensity during demagnetizations, and left diagrams show variation of vector end points. For vector diagrams open (solid) circles are vertical (horizontal) projections.

CS-3 furnace, and in an MS-2 Bartington susceptometer. The heating curves of three representative samples are displayed in Fig. 5. Samples with normal and reversed magnetizations show curves with similar behavior. The magnetic susceptibility remains at low values and fairly constant up to 




(c)

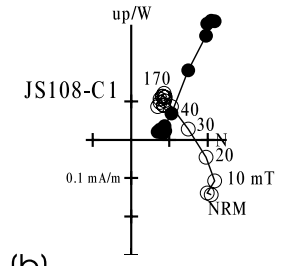

(b)

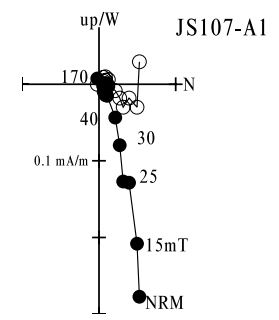

(a)
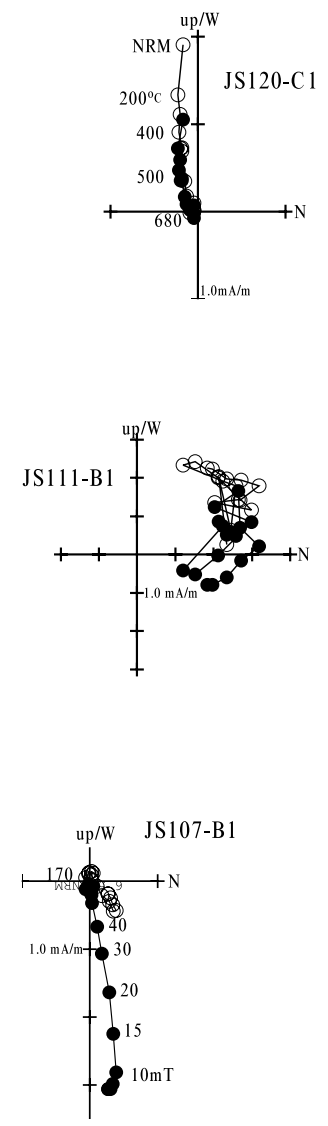
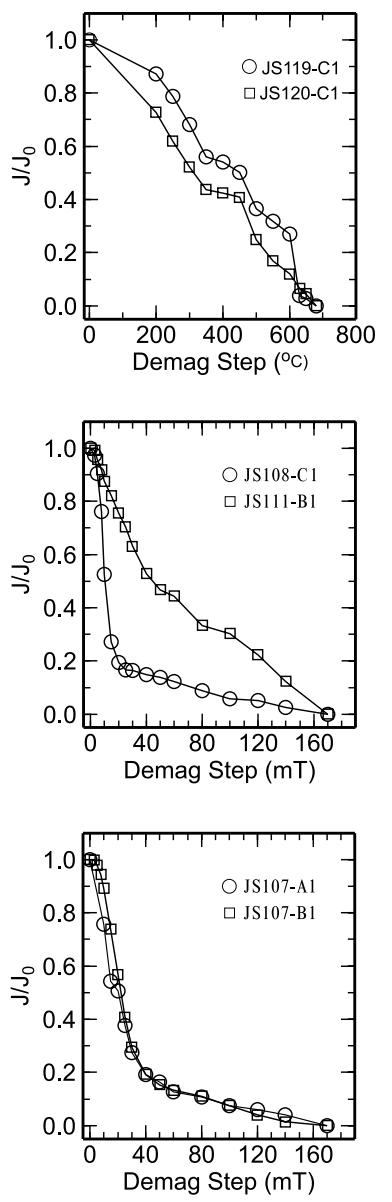

Fig. 4 - Examples of progressive AF and thermal demagnetization results of samples with transitional (a and c) and normal (b) magnetic polarities. Legends are same as in Fig. 3.

$350-400^{\circ} \mathrm{C}$; from 400 to $500^{\circ} \mathrm{C}$ susceptibility shows a sudden increase, reflecting the heating-induced hematite to magnetite reaction and the Hopkinson effect (Nagata 1961), followed by an accentuated drop up to $600^{\circ} \mathrm{C}$. The inferred Curie temperature $\left(\mathrm{T}_{\mathrm{C}}\right)$ is around $555^{\circ} \mathrm{C}$ which characterizes magnetite with low content of titanium (titanomagnetite). The cooling curves have inflection points in the range $530-570^{\circ} \mathrm{C}$ and very large increases in susceptibility, indicating the irreversibility of the chemical changes.

Hysteresis loops for some samples are indicative of large contributions of diamagnetic miner- als (Fig. 6a and c). Hysteresis measurements upon heating samples up to $\sim 700^{\circ} \mathrm{C}$ show that the diamagnetic contributions were minimized and that titanomagnetite is the most important magnetic carrier. The hysteresis loop of sample JS99 (Fig. 6a) is representative of most of the samples throughout the sequences, hinting at very minor changes in grain size or magnetic mineralogy. Saturation magnetization is reached at about $250 \mathrm{mT}$ (Figs. 6a-6d); together with remanence coercivity $\left(\mathrm{H}_{\mathrm{cr}}\right)$ values in the range 40-60 $\mathrm{mT}$ indicates the presence of single domain (SD) to pseudo-single domain (PSD) magnetites. 



Fig. 5 - Susceptibility variation as a function of temperature in a CS3-KLY3 and $\mathrm{MS}_{2}$ Bartington equipments, for samples from the reversed (JS-93), normal (JS-108) and topmost (JS-120) portions of the section.

\section{ANISOTROPY OF MAGNETIC SUSCEPTIBILITY}

Anisotropy of magnetic susceptibility (AMS) provides a measure of the sedimentary fabric that results from a combination of depositional and post depositional factors. AMS is defined by differences in length and orientations of the three principal axes $\left(\mathrm{K}_{1} \geq \mathrm{K}_{2} \geq \mathrm{K}_{3}\right)$ of the magnetic susceptibility ellipsoid defined by the magnetic grains. The AMS of sediments results from the preferred alignment of the longer and shorter axes of the magnetic grains. For sediments deposited in quiet water (lacustrine, fluvial) or quiet wind condition (aeolian), the longer grain axes tend to be randomly distributed in the horizontal plane thereby producing a sedimentary foliation. In such sediments, AMS defines a planar fabric (oblate ellipsoid) with maximum $\left(\mathrm{K}_{1}\right)$ and intermediate $\left(\mathrm{K}_{2}\right)$ axes of nearly equal magnitudes $\left(\mathrm{K}_{1} \approx \mathrm{K}_{2}\right)$ and trending subhorizontally while minimum axis $\left(\mathrm{K}_{3}\right)$ trends subvertically.
The AMS of the Botucatu samples was measured on a KLY-3 Kappabridge susceptometer using a three position measurement procedure at the AMS laboratory of the IGc/USP. A total of 66 samples were measured encompassing sites of reversed (15 samples), normal (14 samples) and anomalous (37 samples) directions. The bulk magnetic susceptibilities $\left(K=\left[K_{1}+K_{2}+K_{3}\right] / 3\right)$ range from $10^{-6}-10^{-4}$ SI (Fig. 7a). No systematic variation is evident along the sections, suggesting a homogenous distribution of the magnetic minerals.

Susceptibility values less than $10^{-4} \mathrm{SI}$ is usually attributed to a dominant contribution of paramagnetic and/or diamagnetic minerals, whereas values higher than $10^{-4} \mathrm{SI}$ indicate the prevailing contribution of magnetite (Tarling and Hrouda 1993). Increasing amounts of magnetite, reflected by higher values of susceptibility, generally has no implications with respect to the degree of anisotropy ( $\mathrm{P}$ $=\mathrm{K}_{1} / \mathrm{K}_{2}$ ), as observed in Fig. $7 \mathrm{~b}$. On the contrary, 



Fig. 6 - Characteristic hysteresis curves for the Botucatu samples acquired in a Molspin Ltd. VSM equipment before $(6 \mathrm{a}$ and $6 \mathrm{c})$ and after $(6 \mathrm{~b}$ and $6 \mathrm{~d})$ heating samples up to $700^{\circ} \mathrm{C}$. Insets show acquisition of isothermal remanent magnetization, and back-field remanent magnetization.

sites where the susceptibility is dominated by diamagnetic phases display higher values of $\mathrm{P}$, reaching 1.6 in Fig. 7b. This is the case for samples carrying normal and intermediate magnetization directions.

The shape parameter $\mathrm{T}\left(\mathrm{T}=\left[2\left(\ln \mathrm{K}_{2}-\ln \mathrm{K}_{3}\right) /\right.\right.$ $\left.\left.\left(\ln \mathrm{K}_{1}-\ln \mathrm{K}_{3}\right)\right]-1\right)$ ranges from -1 (prolate) to +1 (oblate), and defines the shape of the susceptibility ellipsoid (Hrouda 1982, Borradaile 1988, Rochette et al. 1992). For the Botucatu samples both oblate and prolate ellipsoids are found in similar proportions (Fig. 7c). However, oblateness tends to be accentuated in reversed samples, which also tend to display oblate fabrics.
An equal area stereographic projection of the principal susceptibility eigenvectors is shown in Figure 7. Reversed samples (Fig. 7d) show the three principal axes well grouped defining a lineation with the $\mathrm{K}_{1}$ axes horizontally trending in the NNE-SSW direction. This lineation agrees with the general NNE trend of paleocurrent data depicted from an independent study of the Botucatu Formation (Scherer 2000). Samples displaying normal polarity (Fig. 7e) do not show clearly any lineation, although $\mathrm{K}_{1}$ axes tend to cluster an NE direction or an almost vertical direction. Samples with anomalous magnetizations (Fig. 7f) display highly scattered magnetic susceptibility axes. 

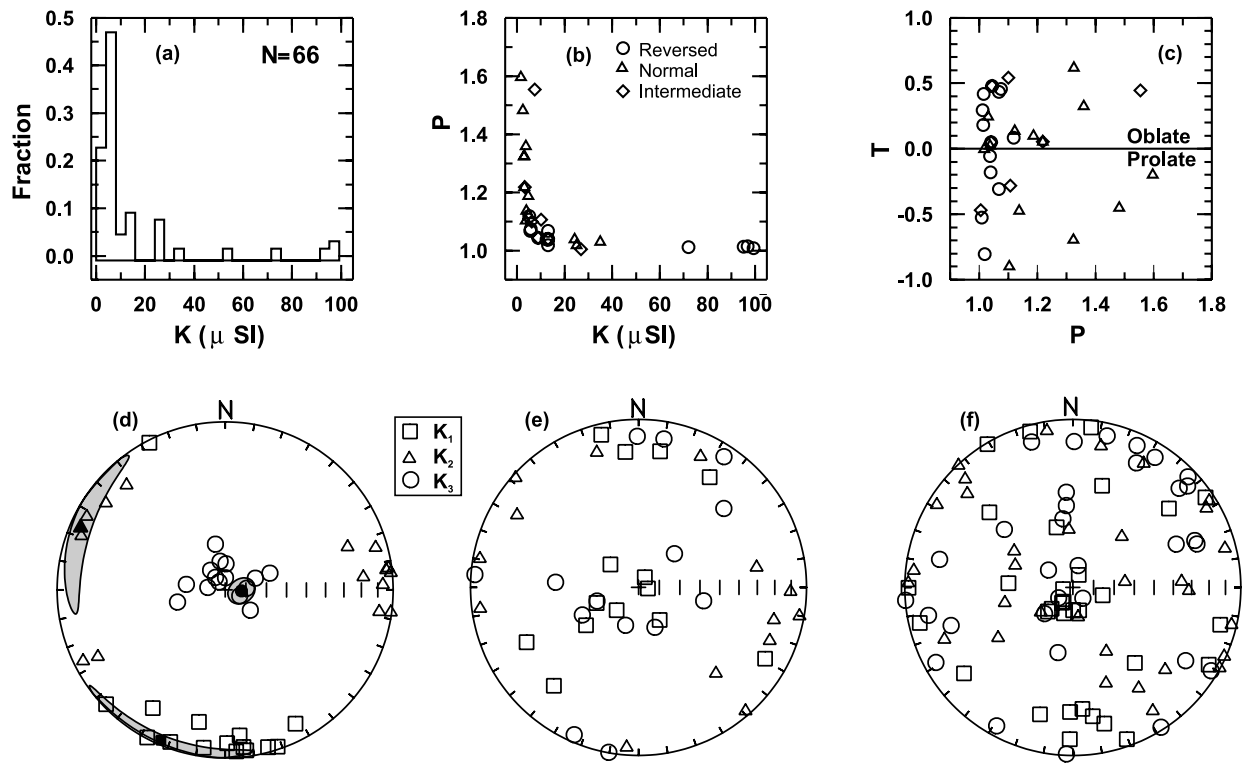

Fig. 7 - (a) Histogram of bulk magnetic susceptibility of 66 Botucatu samples. (b) Degree of anisotropy (P) versus bulk susceptibility. (c) Shape parameter (T) versus $\mathrm{P}$. Equal are projection of principal susceptibility axes for reversed (d), normal (e) and transitional (f) samples. In the (d) diagram the $95 \%$ confidence ellipses are shown.

\section{DISCUSSION AND CONCLUSIONS}

The mean paleomagnetic direction for the 5 normal polarity sites $\left(\mathrm{Dec}=354.6^{\circ}\right.$, Inc $=-45.4^{\circ}$; $\alpha_{95}=8.4^{\circ}, \mathrm{k}=84$ ), and for the 13 reversed polarity sites $\left(\operatorname{Dec}=165.9^{\circ}, \operatorname{Inc}=37.5^{\circ} ; \alpha_{95}=4.6^{\circ}\right.$, $\mathrm{k}=82)$ are significantly different from the local geomagnetic field (Fig. 8). The critical angle between the normal and the reversed means is $10.2^{\circ}$. Under the null hypothesis, the two polarities are drawn from populations with means that are $180^{\circ}$ with a probability of 0.022 of departing from the antipodal condition. Thus, the two sets of directions pass the reversal test of McFadden and McElhinny (1990), implying that the removal of secondary overprints was successful.

Virtual geomagnetic poles (VGPs) were calculated from the mean paleomagnetic directions for each site (Table I), representing the apparent motion of the paleomagnetic pole during the sampled time interval. Figure 9 displays the latitudinal variation of the VGPs through stratigraphy; a transitional field during a field reversal is clearly observed in the bot-

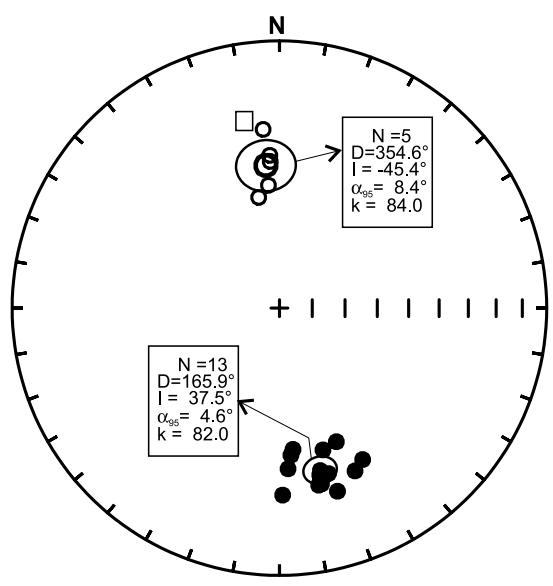

Fig. 8 - Equal area projection of site-mean magnetization directions of normal and reversed polarity of the Botucatu samples.

Solid (open) circles are positive and negative inclinations; square correspond to the local geomagnetic field. Ovals indicate the 95\% confidence limit of the mean directions.

tom part of the section. The five uppermost sites (115-120) show anomalous directions that can be interpreted as records of a transitional field recorded during the normal-to-reversed field. However, given 




(a)

(b)

(c)

Fig. 9 - (a) Lithological column indicating the sample positions; (b) variation of the virtual geomagnetic pole (VGP) latitudes; (c) corresponding magnetic polarity stratigraphy showing normal (black) and reversed (white) polarities. Transitional or anomalous VGPs are indicated by hatched pattern.

the high within-site scatter reflected in the poor confidence parameters, it is highly probable that these sites were influenced by effects of the emplacement of the first flows of the Serra Geral Fm. (normal polarity) a few meters above the sample site. The thermal effects of this emplacement might also explain the incoherence of AMS directions of these sites as heating could produce alterations in the magnetic mineralogy (higher degrees of oxidation), reflected by decreasing of susceptibility. Moreover, most of these samples still preserved about $10 \%$ of the remanence after heating up to $600^{\circ} \mathrm{C}$ during thermal 
demagnetization. Part of the normal polarity sites also displayed AMS direction distribution not typical of a sedimentary process, and they were probably also affected by heating although in a lesser extent. It is important to stress that these two sets of samples (intermediate and normal directions) constitute the upper part of the section (see Fig. 1).

The paleomagnetic pole calculated using both normal and reversed data is located at $77^{\circ} \mathrm{S}, 65^{\circ} \mathrm{E}$ (Table II), which is relatively far from other Mesozoic (Early Cretaceous - Late Triassic) paleomagnetic poles for South America (Fig. 10). Even discarding the normal polarity sites, which may be affected by some remagnetization, the final result does not change significantly (Table I). However, after correcting magnetization directions for a dipping of $15^{\circ}$ to SSW, as observed in some sites, the recalculated paleomagnetic pole $\left(114.7^{\circ} \mathrm{E} 78.5^{\circ} \mathrm{S}\right)$ plots (Fig. 10) close to the apparent polar wander path segment corresponding nearly to the limit Early Cretaceous-Late Jurassic. As shown in Fig. 1 a NWSE fault line passes close to the sampling area justifying the applied correction. Therefore the inferred age of the Botucatu Formation in Rio Grande do Sul might be not older than Late Jurassic. This result must be interpreted as a local result for the thicknesses of the Botucatu sediments vary greatly throughout the Paraná Basin, and might represents the time the reworking of the dunes and redeposition of sediments had already ceased.

\section{CONCLUDING REMARKS}

Investigations of the magnetic mineralogy of the sampled Botucatu rocks indicate that magnetite is the main magnetic carrier although hematite is also present. This fact, together with the high stability of the remanent magnetizations (especially for the samples displaying reversed polarity) are good indications that the isolated characteristic magnetization represents the primary magnetization. AMS results point to the preservation of a magnetic fabric which is consistent with the wind currents determined by other authors (Scherer 2000), and therefore consti-

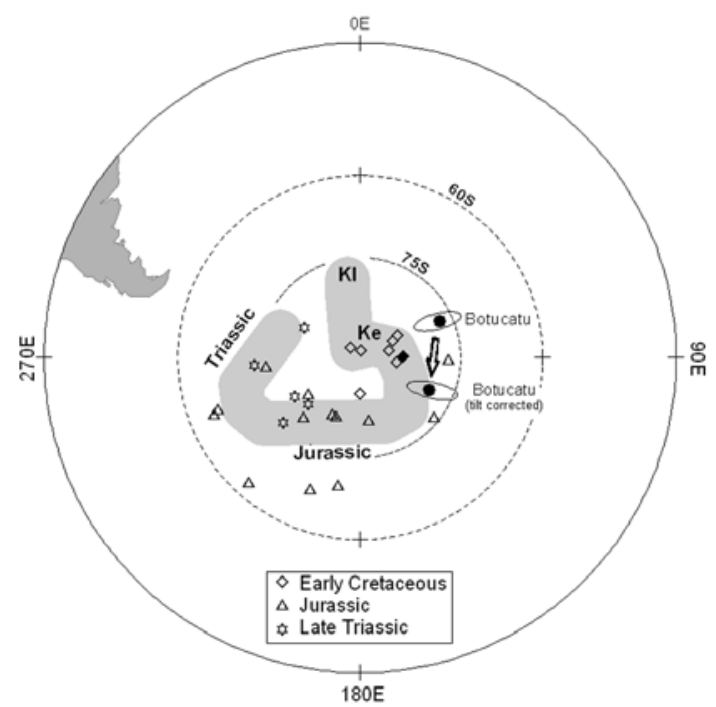

Fig. 10 - Comparison of the Botucatu poles (prior and after tilt correction) with the apparent polar wander path for South America during the Mesozoic, based on paleomagenetic poles compiled by Vizán et al. (2004), Iglesia Llanos et al. (2003) and Ernesto et al. (2002). For reference the Serra Geral pole is heightened (full diamond).

tutes an independent evidence for the preservation of the primary magnetization in those rocks at least in the lower portion of the studied section, which is dominated by reversed polarity magnetizations. The calculated paleomagnetic pole for the Botucatu Formation, after the tectonic correction, is representative of the timing of deposition of those sediments. The position of this tilt-corrected pole indicates a Late Jurassic to Early Cretaceous age for the BF, at least in the sampled locality.

The mean magnetic inclination $\left(35^{\circ}\right.$; after tectonic correction) allows the calculation of the paleolatitude of approximately $21^{\circ} \mathrm{S}$ for the sampling sites. This is ca. $8^{\circ}$ northwards of previous models that require higher latitudes for the formation of the Botucatu dunes. Magnetoestratigraphy identified three polarity intervals recorded during the deposition of the sediments. Based on the high frequency of geomagnetic reversals during the considered time interval it may be concluded that the investigated $\sim 35 \mathrm{~m}$ section covers less than one million years. 
TABLE II

Selected Mesozoic paleomagnetic poles for South America based on compilations by Ernesto et al. (2002), Iglesia Llanos et al. (2003) and Vizán et al. (2004).

\begin{tabular}{|c|c|c|c|c|}
\hline \multirow{2}{*}{ Formation } & Age & Long. & Lat. & $\alpha_{95}$ \\
\hline & (Ma) & $\left({ }^{\circ} \mathrm{E}\right)$ & $\left({ }^{\circ} \mathrm{S}\right)$ & $\left({ }^{\circ}\right)$ \\
\hline Cabo de Santo Agostinho, Brazil & $\sim 100^{*}$ & 315 & 87.6 & 4.5 \\
\hline Cañadón Asfalto Basin, Argentina & $\sim 116$ & 159 & 87 & 3.8 \\
\hline Florianópolis Dikes, SE Brazil & $\sim 121^{\dagger}$ & 3 & 89 & 2.6 \\
\hline Central Alkaline Province, Paraguay & $127-130^{*}$ & 62 & 85 & 3.1 \\
\hline Ponta Grossa Dikes, SE Brazil & $129-131^{\dagger}$ & 58 & 84 & 2.0 \\
\hline Serra Geral Formation, Paraná Basin & $133-132^{\dagger}$ & 89 & 84 & 1.1 \\
\hline Cordoba Province, Argentina & $133-115^{*}$ & 75 & 86 & 3.3 \\
\hline Northeastern Brazil Magmatism-1 & $125-145$ & 97 & 85 & 1.8 \\
\hline Neuquen Basin & $\mathrm{J}_{1}$ & 91 & 77 & 2.0 \\
\hline El Quemado & $153-157$ & 172 & 81 & 7.6 \\
\hline Marifil Formation & $178-183^{\#}$ & 203 & 80 & 8.7 \\
\hline Chon-Aike Formation & $168 \pm 2^{\#}$ & 197 & 85 & 6.0 \\
\hline Mamil Choique Dykes & $168-172$ & 190 & 70 & 9.7 \\
\hline Lepá-Osta Arena Formation & $\mathrm{J}_{\mathrm{e}}$ & 129 & 75 & 6.8 \\
\hline Guacamayas Gr.and Bolivar dikes & $195-199^{*}$ & 265 & 76 & 11.3 \\
\hline French Guyana Dikes & $198-192^{\dagger}$ & 235 & 81 & 4.0 \\
\hline Guyana dykes & Tr-J & 222 & 63 & 12.4 \\
\hline Northeastern Brazil Magmatism-2 & $175-198$ & 223 & 78 & 5.2 \\
\hline Penatecaua Dikes, North Brazil & $164 \pm 26^{*}$ & 249 & 65 & 8.9 \\
\hline Anari-Tapirapuã Lavas, Brazil & $\sim 197^{\dagger}$ & 250 & 65 & 3.6 \\
\hline Rio Blanco & $\operatorname{Tr}_{1}$ & 298 & 81 & 7.6 \\
\hline Ischigualasta & $\operatorname{Tr}_{1}$ & 239 & 79 & 15 \\
\hline Cacheuta & $\operatorname{Tr}_{1}$ & 266 & 75 & 14 \\
\hline Puesto Viejo & $\operatorname{Tr}_{\mathrm{m}}$ & 230 & 75 & 16 \\
\hline Cuesta Terneros & $\operatorname{Trm}$ & 228 & 80 & 10 \\
\hline
\end{tabular}

${ }^{*} \mathrm{~K}$-Ar ages; ${ }^{\dagger 40} \mathrm{Ar} /{ }^{39} \mathrm{Ar}$ ages; ${ }^{\#} \mathrm{Rb}-\mathrm{Sr}$ ages; $\mathrm{J}_{1}=$ Late Jurassic; $\mathrm{J}_{\mathrm{e}}=$ Early Jurassic; $\operatorname{Tr}_{1}=$ Late Triassic; $\operatorname{Tr}_{\mathrm{m}}=$ mid Triassic.

\section{ACKNOWLEDGMENTS}

We are grateful to P.R. Renne for the use of $2 \mathrm{G}$-Enterprise cryogenic magnetometer housed in magnetically shielded room at Berkeley Geochronologic Center, R. Siqueira for helping with sample measurements, M.I.B. Raposo for permission to use the KLY-3S instrument at the Instituto de Geociências (IGc/USP). Thanks are also due to M.L. Assine for his valuable contributions. The completion of this paper was assisted by a grant from
Fundação de Amparo à Pesquisa do Estado de São Paulo (FAPESP) to the first author (E.T). E. Tohver and two anonymous reviewers greatly contributed to improve the paper.

\section{RESUMO}

Dados paleomagnéticos e de magnetismo de rochas dos sedimentos eólicos da Formação Botucatu, no Estado do Rio Grande do Sul, obtidos de uma seção localizada entre as cidades de Jaguari e Santiago, permitiram definir a idade dessa formação. Direções de magnetização carac- 
terísticas com polaridades normal e reversa foram obtidas após desmagnetizações térmicas e por campos magnéticos alternados. Do total de sítios amostrados 13 apresentaram polaridade reversa e 5, polaridade normal, compondo uma coluna magnetoestratigráfica onde se identificam três horizontes de polaridade, na ordem, reversonormal-reverso. O pólo paleomagnético baseado em 18 sítios está localizado a $114.7^{\circ} \mathrm{E}, 78.5^{\circ} \mathrm{S}\left(\mathrm{dp}=8.1^{\circ} ; \mathrm{dm}\right.$ $=1.2^{\circ}$ ), depois de restaurada a paleohorizontal dos sítios de amostragem. Este pólo paleomagnético indica idade do Jurássico Superior-Cretáceo Inferior para a Formação Botucatu na área estudada, e indica que as paleolatitudes ocupadas eram da ordem de $21^{\circ} \mathrm{S}$.

Palavras-chave: Paleomagnetismo, Formação Botucatu, magnetoestratigrafia, anisotropia magnética, Jurássico Superior.

\section{REFERENCES}

AlmeidA F. 1954. Botucatu, um deserto triássico da América do Sul. DNPM Div Geol Min, Notas Prel e Estudos 86, $21 \mathrm{p}$.

Almeida F And Melo C. 1981. A Bacia do Paraná e o vulcanismo mesozóico. In: BISTRICHI CA, CARniero CDR, DANTAS ASL AND PonçANo WL (Eds), Mapa geológico do Estado de São Paulonota explicativa. Instituto de Pesquisas Tecnológicas 1: 46-77.

Assine ML, Piranha JM and Carneiro CDR. 2004. Os paleodesertos Pirambóia e Botucatu. In: Mantesso-Neto V, Bartorelli A, Carneiro CDR AND BRITo-Neves BB (Eds), Geologia do Continente Sul-Americano: evolução da obra de Fernando Flávio Marques de Almeida. SP, Brasil: Beca Prod Cult Ltda, p. 77-92.

Bertini RJ. 1993. Paleobiologia do Triássico-Jurássico da porção centro-nordeste da Bacia do Paraná: estado da arte e perspectivas futuras. Simpósio sobre Cronoestratigrafia da Bacia do Paraná, Rio Claro. Resumos 86-89.

BorRADAILE GJ. 1988. Magnetic susceptibility, petrofabrics and strain. Tectonophysics 156: 1-20.

Dias-Brito D, Musacchio EA, Castro JC, MARANHÃO MSAS, SUÁREZ JM AND RODRIGUES R. 2001. Grupo Bauru: uma unidade continental do Cretáceo no Brasil - concepções baseadas em dados micropaleontológicos, isotópicos e estratigráficos. Revue Paléobiol 20: 245-304.

ERnesto M, Pacca IG, Hiodo FY AND NARdy AJR. 1990. Paleomagnetism of the Mesozoic Serra Geral Formation, southern Brazil. Phys Earth Planet Int 64: 153-175.

Ernesto M, Bellieni G, Piccirillo EM, MarQues LS, DE Min A, PACCA IG, Martins G AND MACEDO JWP. 2002. Paleomagnetic, geochronological and geochemical constraints on time and duration of the Mesozoic igneous activity in Northeastern Brazil. In: The Central Atlantic Magmatic Province, AGU Monograph 136: 129-149.

FISHER RA. 1953. Distribution on a sphere. Proc R Soc London A217: 295-305.

HroudA F. 1982. Magnetic anisotropy of rocks and remanence: developments in the characterization of tectonic, sedimentary, and igneous fabric. Rev Geophys 29: 371-376.

Iglesia Llanos MP, LANZA R, Geuna S, LAURENZI MA AND RUFFINI R. 2003. Palaeomagnetic study of the El Quemado complex and Marifil formation, Patagonian Jurassic province, Argentina. Geophys J Int 154: 599-617.

KIRSCHVINK JL. 1980. The least square line and plane and the analysis of paleomagnetic data. Geophys J R Astron Soc 62: 699-718.

LEONARDI G AND OLIVEIRA FH. 1990. A revision of the Triassic and Jurassic tetrapod footprints of Argentina and a new approach on the age and meaning of the Botucatu formation footprints (Brazil). Rev Bras Geoc 20: 216-229.

McFadden PL and McElhinny MW. 1990. Classification of the reversal test in paleomagnetism. Geophys J Int 103: 725-729.

Milani E, Faccini U, Schere C, Araujo L and Cupertino L. 1999. Sequences and stratigraphic hierarchy of the Paraná Basin (Ordovician to Cretaceous), Southern Brazil, Série Científica, Bol. IGUSP, SP, Brazil 29: 125-173.

NagatA T. 1961. Rock magnetism. Maruzen, Tokyo. Rochette P, Jackson MJ AND Aubourg C. 1992. Rock magnetism and the interpretation of anisotropy of magnetic susceptibility. Rev Geophys 30: 209-226. 
SALAMUNi R AND BigARElla JJ. 1967. Botucatu Formation. In: BIGARELlA JJ, BECKER RD AND PINTO ID (Eds), Problems in Brazilian Gondwana Geology. Curitiba, PR, Brazil: p. 197-206.

SCHERER C. 2000. Aeolian dunes of the Botucatu Formation (Cretaceous) in southernmost Brazil: morphology and origin. Sed Geol 137: 63-84.

SoARES PC. 1975. Divisão estratigráfica do Mesozóico no Estado de São Paulo. Rev Bras Geoc 5: 229-252.

TARLING DH AND HROUdA F. 1993. The magnetic anisotropy of rocks. Chapman \& Hall, London, $217 \mathrm{p}$.
VIZÁN H, IXER R, TURNER P, CORTÉS JM AND Cladera G. 2004. Paleomagnetism of Upper Triassic rocks in the Los Colorados hill section, Mendoza province, Argentina. J South Am Earth Sci 18: 41-59.

ZIJDERVELD JDA. 1967. AC demagnetization of rocks: Analysis of results. In: COLLINSON DW, CREER KM AND RUnCORn SK (Eds), Methods in Paleomagnetism, Amsterdam: Elsevier, p. 254-286. 